OPEN ACCESS

Edited by:

Krystal S. Tsosie,

Vanderbilt University, United States

Reviewed by:

Alexjandro C. Daviano,

Texas A\&M University, United States

Melinda Stolley,

Medical College of Wisconsin,

United States

*Correspondence:

Raheem J. Paxton rpaxton@UA.edu

Specialty section

This article was submitted to Cancer Epidemiology and Prevention,

a section of the journal

Frontiers in Oncology

Received: 17 April 2018 Accepted: 02 January 2019 Published: 22 January 2019

Citation:

Paxton RJ, Garner W, Dean LT, Logan G and Allen-Watts K (2019)

Health Behaviors and Lifestyle

Interventions in African American

Breast Cancer Survivors: A Review.

Front. Oncol. 9:3.

doi: 10.3389/fonc.2019.00003

\section{Health Behaviors and Lifestyle Interventions in African American Breast Cancer Survivors: A Review}

\author{
Raheem J. Paxton ${ }^{1 *}$, William Garner ${ }^{2}$, Lorraine T. Dean ${ }^{3}$, Georgiana Logan ${ }^{1}$ and \\ Kristen Allen-Watts ${ }^{1}$ \\ ${ }^{1}$ Department of Community Medicine and Population Health, The University of Alabama, Tuscaloosa, AL, United States, \\ ${ }^{2}$ Department of Life and Health Sciences, University of North Texas at Dallas, Dallas, TX, United States, ${ }^{3}$ Department of \\ Epidemiology, John Hopkins School of Public Health, Baltimore, MD, United States
}

Background: African American breast cancer survivors have a higher incidence of estrogen receptor negative and basal-like (e.g., triple negative) tumors, placing them at greater risk for poorer survival when compared to women of other racial and ethnic groups. While access to equitable care, late disease stage at diagnosis, tumor biology, and sociodemographic characteristics contribute to health disparities, poor lifestyle characteristics (i.e., inactivity, obesity, and poor diet) contribute equally to these disparities. Lifestyle interventions hold promise in shielding African American survivors from second cancers, comorbidities, and premature mortality, but they are often underrepresented in studies promoting positive behaviors. This review examined the available literature to document health behaviors and lifestyle intervention (i.e., obesity, physical activity, and sedentary behavior) studies in African American breast cancer survivors.

Methods: We used PubMed, Academic Search Premier, and Scopus to identify cross-sectional and intervention studies examining the lifestyle behaviors of African American breast cancer survivors. Identified intervention studies were assessed for risk of bias. Other articles were identified and described to provide context for the review.

Results: Our systematic review identified 226 relevant articles. The cross-sectional articles indicated poor adherence to physical activity and dietary intake and high rates of overweight and obesity. The 16 identified intervention studies indicated reasonable to modest study adherence rates (>70\%), significant reductions in weight (range -1.9 to $-3.6 \%)$, sedentary behavior (-18\%), and dietary fat intake (range -13 to $-33 \%$ ) and improvements in fruit and vegetable intake (range +25 to $+55 \%$ ) and physical activity (range +13 to $+544 \%)$. The risk of bias for most studies were rated as high (44\%) or moderate (44\%).

Conclusions: The available literature suggests that African American breast cancer survivors adhere to interventions of various modalities and are capable of making modest to significant changes. Future studies should consider examining (a) mediators and moderators of lifestyle behaviors and interventions, (b) biological outcomes, and (c) determinants of enhanced survival in this population.

Keywords: African American, breast cancer, cancer survivor, cancer survivorship, diet, physical activity, review, obesity 


\section{INTRODUCTION}

The number of African American (AA) cancer survivors continues to increase (1). Despite this rapid increase, AAs are especially vulnerable to poor health outcomes. In particular, AA breast cancer survivors are at risk for second cancers and comorbid conditions that threaten their ability to live independently (2). Developing health promotion and disease prevention interventions for this population will reduce their risk for adverse outcomes following diagnosis. However, before developing such interventions, there is an urgent need to (a) understand the mechanisms that contribute to poor health outcomes and (b) review relevant health behavior and intervention studies that have been conducted in this population.

\section{Rationale}

There are key indicators that contribute to cancer-related disparities between AA and non-Hispanic white (NHW) breast cancer survivors. Racial differences in tumor characteristics may contribute to the survival disparities between AA and NHW women (3-6). For example, several studies indicated that AA women were more likely to develop highly aggressive (7), "basallike" tumors of the triple-negative subtype, but less likely than NHW women of the same ages to develop less aggressive, more treatable "luminal" tumors (8-17). While these data partially support the genetic admixture hypothesis or differences in tumor biology, socio-political constructs such as racism and segregation may be equally important (18). Several authors have indicated that AA women born in southern states with long-lasting vestiges of slavery (i.e., Jim Crow laws) $(19,20)$, as well as those exposed to persistent weathering from poor social environments are more likely than NHW women to be diagnosed with aggressive tumors $(18,21)$. Furthermore, others speculate that comorbidities are significant culprits behind the mortality disparities that exist between AA and NHW breast cancer survivors (22). In a historical cohort from the Henry Ford Health System, Tammemagi et al. (22) found that comorbidities accounted for nearly $50 \%$ of the overall and competing-cause survival disparity between AA and NHW women. The combination of these factors contributes to the health disparities that exist between AA and NHW breast cancer survivors.

The literature presented above, while informative, neglects critical elements that may shield AA breast cancer survivors from poor outcomes. These data assumes that health and wellness occur in a vacuum and that preventive behaviors such as diet and exercise are not relevant. As such, the body of literature describing AA cancer survivors has focused on differences in cancer-specific and overall outcomes but has failed to study extensively the factors that promote health.

\section{Objectives}

Recent comprehensive reviews have documented the importance of healthy lifestyle factors in improving the health and wellbeing of cancer survivors (23-26). Lifestyle interventions hold promise in shielding African American survivors from second cancers, comorbidities, and premature mortality, but they are underrepresented in these studies. Studies that summarize the state of AA breast cancer survivorship may help to document the successes and opportunities that move the field forward. Therefore, the objectives of this review were to summarize published intervention studies documenting the efficacy or effectiveness of diet, exercise, and weight loss interventions in AA breast cancer survivors.

\section{Research Aims}

The aims of this review were to (a) summarized key cohort, crosssectional, and randomized trials; (b) examine published literature to document the efficacy or effectiveness of health behavior (i.e., diet, physical activity, and weight loss/maintenance) intervention studies conducted in AA in breast cancer survivors; and (c) propose strategies for moving the field of AA breast cancer survivorship forward. The information gained from this study may shed light on the strengths, weaknesses, and opportunities to enhance the health and well-being of AA breast cancer survivors.

\section{METHODS}

\section{Study Design}

All types of study designs were identified and evaluated. The designs included cross-sectional, cohort, quasi-experimental, and randomized designs.

\section{Participants and Interventions}

The participants were breast cancer survivors aged 18 years and older. However, we also included studies that focused exclusively on AA breast cancer survivors. The interventions were designed to improve physical activity and dietary intake and decrease sedentary behavior (i.e., prolonged sitting), dietary fat, or weight.

\section{Systematic Review Protocol}

Although this is a general review study, we applied an approach similar to a systematic review to examine the articles. Two authors confirmed the inclusion and exclusion criteria as well as conducted the independent reviews. There were no disagreements that required a third party to adjudicate.

\section{Data Sources and Search Strategy}

We searched three databases (PubMed, Academic Search Premier, and Scopus) with the following search terms-cancer survivor*, African American, breast neoplasm, and lifestyle behaviors (physical activity OR diet, OR sedentary behavior OR prolonged sitting OR weight loss OR weight management). The exclusion criteria were non-English language studies; theses or dissertations (not published in peer-reviewed journals); qualitative studies, and studies that did not report primary data for AA breast cancer survivors. We also excluded AA studies that focused exclusively on psychosocial variables (i.e., self-efficacy and quality of life) or those that did not have a focus on lifestyle behaviors as the primary independent or dependent variable. Also, we incorporated a separate search for seminal articles in the field that documented the state of cancer survivorship research. Many of these studies represented large randomized controlled trials, large cohort studies, or secondary analyses of these studies. 
The select studies identified were included in our search totals and used to guide our review of the literature. The time frame was limited from 1999 to October 2018. Select cross-sectional studies were reported on due to our emphasis on intervention studies.

\section{Data Analysis}

The identified articles were used to create a flow diagram. The inclusion and exclusion criteria described above was used to determine the articles that were reviewed. The intervention studies were rated based on unique characteristics that determined the risk of bias. We selected 3 criteria to determine bias in the identified intervention studies. The criteria were based on the Cochrane Handbook for Systematic Reviews of Intervention (27). The criteria used included the (a) sample size, (b) study design, and (c) validity of the outcome measure. Sample sizes of $<30,30$ to 49 , and 50 or higher were characterized as low, moderate, and high quality, respectively. Randomized trials were characterized as high quality, while other designs were characterized as low quality. Objectively assessed anthropometric, dietary, and physical activity outcomes were characterized as high quality, whereas self-reported outcomes were characterized as low quality. Each rating was transformed to a numerical, whereby scores of 11,22 , and 33 characterized as low, moderate, and high quality, respectively. Scores were summed across categories. Total scores of $<60,60$ to $<99$, and 99 were characterized as high, moderate, and low bias studies.

\section{RESULTS}

\section{Study Selection Characteristics and Flow Diagram}

A total of 226 total articles were identified. Some articles were redundant across databases or did not meet our inclusion criteria $(N=26)$. A total of 94 articles were reviewed comprehensively by our research team. Of the 94 articles identified, 65 pertained to seminal research in the field of cancer survivorship that provided a context for the 29 articles that were selected to characterize the health behaviors of AA breast cancer survivors. Sixteen of the 29 studies were unique intervention studies. Figure $\mathbf{1}$ depicts an image of our flow diagram.

\section{Synthesized Findings \\ Review of Lifestyle Factors in AA Breast Cancer Survivors \\ Obesity and weight gain}

Studies have repeatedly shown that the relationship between body mass index (BMI) and breast cancer is not the same for AA and NHW women $(28,29)$. Excess weight gain after the age of 18 for AA women was associated with early onset (or premenopausal), estrogen-receptor negative, and triple negative breast cancers (30-33). Large cohort and national studies also indicate that $\mathrm{AA}$ breast cancer survivors have higher rates of obesity (body mass index $[\mathrm{BMI}] \geq 30 \mathrm{~kg} / \mathrm{m}^{2}$ ) (34-36), and gain more weight following treatment than women of other racial and ethnic groups (37).

Weight status and post-diagnosis weight gain may be the immediate causal factor in the poor prognostic outcomes experienced by AA women (38-40). Nichols et al. (41) found that obesity before diagnosis was associated with greater mortality in breast cancer survivors. Also, post-diagnosis weight gain of $>10 \mathrm{~kg}$ was associated with a $12-13 \%$ increase in mortality. Similarly, two recent meta-analyses found that obesity was associated with a $41 \%$ increase in all-cause mortality and that overweight and obesity were associated consistently with treatment-related cardiotoxicity $(42,43)$. Although these studies refer to breast cancer survivors overall, we speculate that AA breast cancer survivors have a higher incidence of these chronic health conditions when compared to NHW breast cancer survivors. Thus, the disparities in survival between AA and NHW breast cancer survivors may be due partially to obesity and obesity-related consequences (e.g., comorbidities and cardiotoxicity).

\section{Dietary intake}

According to the American Cancer Society (ACS), cancer survivors should consume a diet high in fruits, vegetables, whole grains, and low in added sugars, red and processed meats (44). A meta-analysis of cohort studies indicated that adherence to dietary guidelines reduces cancer-specific mortality (45). Accordingly, cohort studies have found that participants adhering to the ACS dietary guidelines or a prudent diet experienced a $15-43 \%$ reduction in all-cause mortality and a $29 \%$

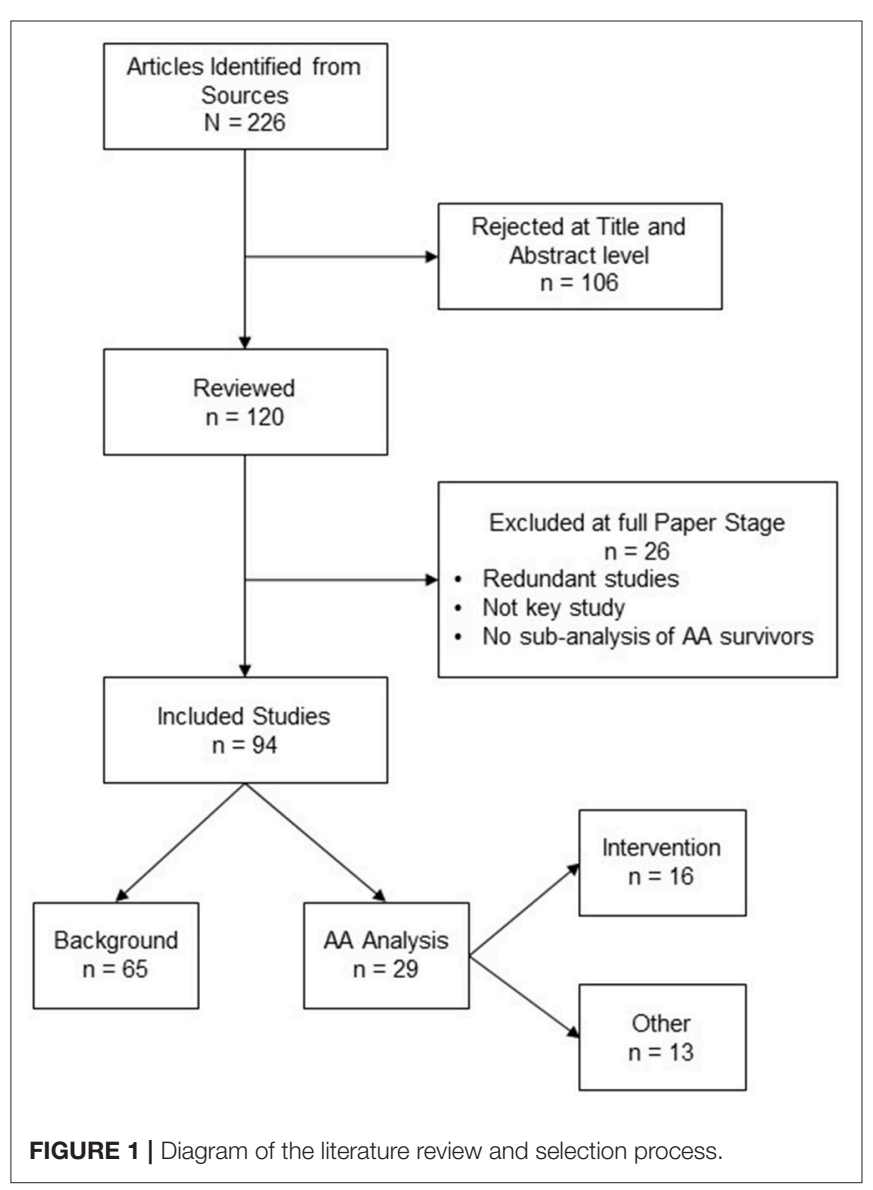


reduction in cancer recurrence (46-48). However, the protective effect of diet was not observed in all studies $(46,48)$.

Adherence to the American Cancer Society (44) dietary guidelines has not been studied extensively in AA breast cancer survivors. Paxton et al. (49) observed that AA breast cancer survivors consumed more fat, but consumed fewer daily servings of fruits and vegetables than NHW breast cancer survivors consume. Similarly, Ramirez et al. (50) found that $84 \%$ met guidelines for consumption of red and process meet, but most $(80 \%)$ did not meet guidelines to fruit and vegetable consumption. Other studies in smaller samples of AA breast cancer survivors observed that more than two-thirds of AA breast cancer survivors exceeded the recommended daily intake of saturated fat, total fat, and added sugars $(51,52)$.

\section{Physical activity}

Physical activity has been associated with several benefits for cancer survivors across the cancer continuum (53-55) including a reduced risk of breast cancer-related mortality (56-59). In the Women's Healthy Eating and Living (WHEL) Study (59), women who were most active at baseline had a 53\% lower mortality risk than those who were the least active. Similar results were observed for women in the Nurses' Health Study, (57) the Collaborative Women's Longevity Study (56), and the Health, Eating, Activity, and Lifestyle (HEAL) Study (60). Also, recent meta-analyses of controlled intervention trials of survivors showed that physical activity was associated with improvements in cardiorespiratory fitness, body mass index (BMI), percent body fat, upper and lower body strength, and health-related quality of life $(54,55)$. Similarly, positive improvements in health-related quality of life (HRQOL) were observed with resistance training $(61,62)$. Overall, physical activity is well tolerated during and after treatment and has minimal side effects $(61,63)$.

Despite the benefits associated with physical activity, many cancer survivors fail to meet current recommendations ( $\geq 30 \mathrm{~min}$ of moderate to vigorous physical activity on $\geq 5$ days per week), and the rates of compliance have been lowest for AA breast cancer survivors $(35,49)$. In a secondary analysis of the WHEL study, Paxton et al. observed that $40 \%$ of AA breast cancer survivors met physical activity guidelines when compared to $60 \%$ of NHW breast cancer survivors (35). In the HEAL Study, only $24 \%$ of AA breast cancer survivors were compliant with guidelines $(36,64)$. Prior studies conducted in survivors recruited from community-based organizations have yielded higher compliance rates $(65,66)$. However, these rates may not be representative of AA breast cancer survivors nationwide.

Several studies have examined the relationship between physical activity and health-related quality of life in AA breast cancer survivors $(35,36)$. Physical activity has been associated consistently with physical function $(35,36,65)$. In a sample of AA and Hispanic breast cancer survivors, Millet et al. (67) found that those who were physically active had better health-related quality of life scores than those who were not. Physical activity was also consistently associated with overall health-related quality of life and vitality (or energy/fatigue) $(35,36)$. Paxton et al. found that those meeting physical activity guidelines had better overall health-related quality of life, physical health, role limitations due to physical and emotional health, general health, mental health, and vitality than those who did not. Similarly, Smith et al. (65) found that those who met physical activity guidelines were better able to perform activities of daily living (e.g., going up and down stairs \& performing household chores) and had lower levels of pain than those not meeting guidelines. Moreover, Diggins et al. (68) in a prospective study found those AA survivors who were physically active experienced greater improvements in mood as well as social, spiritual, and physical health than those who were not. Overall, the literature confirms associations between physical activity and both physical and mental health outcomes.

\section{Sedentary behavior (SB)}

SB can be defined as any "waking" activity characterized by energy expenditure between 0.75 and 1.5 metabolic equivalents and a sitting or reclining posture (69). SBs include, but are not limited to, screen time (i.e., television viewing or computer usage), riding in or driving an automobile, and sitting or reclining while engaged in leisure activities (i.e., reading, talking on the phone, eating, arts and crafts) (70). SB has emerged as an important risk factor for several chronic health conditions (e.g., breast cancer, heart disease, and diabetes) (71-75). In a sample of breast survivors, Phillips et al. (76) observed that with every quartile increase in sedentary time, mean levels of fatigue increased. Similarly, George et al. (77) using data from the HEAL Study observed that SB was associated with lower levels of physical functioning ( $\beta=-0.50, p=0.03$ ), general health ( $\beta$ $=-0.75, p<0.01)$, and overall physical health $(\beta=-0.35, p$ $<0.01$ ). We have not identified any studies that have examined the consequences of $\mathrm{SB}$ or breaks from prolonged sitting in $\mathrm{AA}$ breast cancer survivors. However, Paxton et al. (78) in a mixed methods study observed that AA survivors self-reported sitting up to $12.1 \mathrm{~h}$ per day for those who reported both leisure-time and work-related sitting. Additional research is needed to understand the antecedents and consequences of SB in both AA and NHW breast cancer survivors.

\section{Intervention Studies in Breast Cancer Survivors Weight loss studies in breast cancer survivors}

Several studies have evaluated weight loss interventions in breast cancer survivors (79-84), and several more are ongoing (8587). The Lifestyle Intervention study in Adjuvant Treatment of Early Breast Cancer (LISA) and the Exercise and Nutrition to Enhance Recovery and Good Health to You (ENERGY) trials were the largest $(79,80)$. The LISA trial compared the effectiveness of a telephone-delivered lifestyle intervention vs. a brief, mail-based intervention condition. The lifestyle condition lost approximately $5.5 \%$ of total weight compared to $<1 \%$ for the mail-based condition. Unfortunately, the LISA trial was terminated early due to loss of funding (88). The ENERGY trial was primarily a group-based study supplemented with telephone counseling calls and tailored newsletters. Weight loss at 12 -months in the intervention condition was approximately $6 \%$ compared to $1.5 \%$ in the control condition, and significant differences were maintained at the 24-month 
follow-up assessment. Analyses are underway to determine the impact of the intervention on cancer recurrence and survival.

\section{Weight loss intervention in AA breast cancer survivors}

Few randomized weight loss interventions exist for AA breast cancer survivors $(81,89)$. In our review, we identified eight weight loss studies $(52,81,89-94)$. Five of the eight studies used randomized designs $(81,89,91-93)$. Four out of the eight resulted in statistically significant reductions in weight $(52,89$, 92, 94). The Life Study (91) observed significant weight loss, but the change in weight was not significantly different from that of the comparison or control condition. Moving Forward II was the largest of the studies (89). Stolley et al. (89) found that a community-based weight loss intervention tailored to AA breast cancer survivors resulted in significant weight loss. The behavioral change strategies of Moving Forward II included selfmonitoring, goal setting, self-efficacy, and social support. The remaining studies had sample sizes of $<45$ participants. Of note, two of the studies measured cancer-related biomarkers $(93,94)$ and one used web-based monitoring with wireless/Bluetooth scales and activity trackers (93). Delgado-Cruzata et al. (94) did not observe changes in plasma biomarkers but was able to show that women who lost $\geq 2 \%$ of body fat experienced an improvement in the plasma biomarkers. Valle et al. (93) in a 3arm trial using Facebook, wireless scales, and activity trackers, observed significant reductions in blood pressure. Overall, weight loss across the studies ranged from $-1.9 \%$ (94) to $-3.6 \%$ of weight (89). The weight loss studies were reported in Table $\mathbf{1}$.

\section{Summary of identified weight loss intervention in AA breast cancer survivors}

Overall, the weight loss studies conducted in AA breast cancer survivors have shown tremendous progress in the last decade. However, there is a need for more studies. In particular, future studies should: (a) consider examining cancerrelated biomarkers, (b) ensure that studies are adequately powered to detect within- and between-group differences, and (c) use randomized designs. Research should also consider incorporating stepped-care or adaptive designs or those that provide more support for women who are not successful in the intervention condition. Future studies should also consider partner-based interventions to enhance the effectiveness of studies conducted in community-based settings (52). Daughters and Mothers Against Breast Cancer (DAMES) was a successful trial that recruited mother and daughter dyads (82). Interventions such as DAMES may help to combat the negative support that AA women experience in changing their diet and exercise behaviors.

\section{Dietary intervention studies in breast cancer survivors}

The Women's Intervention Nutrition Study (WINS) (95) and the Women's Health Eating and Living (WHEL) Study (96) were designed to test the impact of dietary interventions on breast cancer recurrence and survival. WINS emphasized a low-fat diet ( $\leq 15 \%$ of calories from fat), whereas the WHEL Study emphasized a diet high in fruits and vegetables (F\&V; $\geq 8$ servings/day) and fiber ( $\geq 30 \mathrm{~g} /$ day $)$ and low in fat ( $\leq 20 \%$ of calories from fat). The WINS found that a 6 pound reduction in weight and a 19 gram reduction in dietary fat intake was associated with a $\sim 24 \%$ lower risk for breast cancer recurrence. The reduction in breast cancer recurrence was more pronounced in women who had node-negative tumors, relative to women with other tumor characteristics ( $42 \%)(95)$. Secondary analysis of the WHEL Study showed that a higher intake of F\&Vs at baseline was associated with a reduced risk for breast cancer recurrence $(H R=0.7,95 \% C I=0.6-0.9)$, particularly for survivors who reported tamoxifen ( $\mathrm{HR}=0.6,95 \% \mathrm{CI}=0.4-0.8)$ use (97). However, the WHEL Study dietary intervention did not yield significant improvements in cancer-related outcomes.

\section{Diet trials in AA breast cancer survivors}

We identified three dietary intervention studies that focused on AAs or included a sub-analysis of AAs $(49,98,99)$. Secondary analysis of the WHEL study indicated that AA breast cancer survivors were able to increase their intake of fiber, fruits, and vegetables (49). Improvements in fiber and servings of fruits were maintained at the 4-year follow-up assessment. The WHEL study used a combination of intensive telephone counseling, newsletters, and cooking classing. Griffith et al. (98) used a culturally tailored version of WINS (i.e., WINS-C). The study resulted in a minor reduction of dietary fat consumption. WINSC used a combination of coaching sessions with a registered dietician, group sessions, and follow-up telephone calls. Paxton et al. (99) in a randomized parallel-group design, observed positive trends in dietary intake, albeit not significantly different from that of the comparison group. Paxton et al. used a fully automated web-based program that utilized automated calls and encouraged goal setting and self-monitoring. Improvements in fruit and vegetable intake across the studies ranged from $+25 \%$ (99) to $+55 \%$ (49). Reductions in dietary fat intake across the studies ranged from $13 \%$ (49) to $31 \%$ (98).

\section{Summary of dietary interventions in AA breast cancer survivors}

Overall, dietary intervention studies in cancer survivors have not yielded promising results and have led many to believe that the relationships between diet and cancer prognosis may be inconclusive (100-102). Examining dietary patterns may help to uncover relationships that were not realized in interventions focused on intervening on a few nutrients or foods. Studies that personalize interventions to AAs and their food preferences are needed to enhance research in this population. Furthermore, there is a need to study the dietary patterns of AA breast cancer survivors and the role that specific patterns have on to cancerspecific outcomes. A summary of the dietary interventions was reported in Table 2.

\section{Physical activity studies in breast cancer survivors}

There are numerous studies in the literature outlining the benefits of regular physical activity for breast cancer survivors. Overall, these studies are positive and indicate that homeand community-based interventions are effective in improving physical activity $(23,103)$. More recently, there has been a push to examine the efficacy of physical activity on cancer-specific 
TABLE 1 | Identified weight loss intervention studies in African American breast cancer survivors.

\begin{tabular}{|c|c|c|c|}
\hline Study & Sample & Intervention & Outcomes \\
\hline $\begin{array}{l}\text { Moving Forward II } \\
\text { Stolley et al. (89) }\end{array}$ & $\begin{array}{l}\text { Sample size: } 246 \text { AA } \\
\text { Mean age: } 58 \text { years } \\
\text { Mean BMl: } 36 \mathrm{~kg} / \mathrm{m}^{2} \\
\text { Mean years } \\
\text { post-diagnosis: } 7 \\
\text { years }\end{array}$ & $\begin{array}{l}\text { Randomized to a 6-month weight loss } \\
\text { intervention (interventionist-guided vs. } \\
\text { self-guided) } \\
\text { Social Ecological Model }\end{array}$ & $\begin{array}{l}\text { Weight: }-3.5 \text { vs. }-1.3 \%{ }^{*} \\
\text { PA (minutes/week): }+98.4 \text { vs. }+60.6 \\
\text { Diet ( } \% \text { Cal Fat): }-2.1 \% \text { vs. }-0.7 \%\end{array}$ \\
\hline $\begin{array}{l}\text { WELL Body } \\
\text { Valle et al. (93) }\end{array}$ & $\begin{array}{l}\text { Sample size: } 35 \text { AA } \\
\text { Mean age: } 53 \text { years } \\
\text { Mean BMl: } 34 \mathrm{~kg} / \mathrm{m}^{2} \\
\text { Mean years } \\
\text { post-diagnosis: } 3 \\
\text { years }\end{array}$ & $\begin{array}{l}\text { Randomized to a 6-month self-regulation } \\
\text { intervention with and without an activity } \\
\text { monitor or a delayed intervention control } \\
\text { Self-regulation Theory }\end{array}$ & $\begin{array}{l}\text { Weight: }-0.9 \text { vs. }-0.2 \text { vs. }+0.8 \% \\
\text { PA (Kcal/week): }+432 \text { vs. }+72 \\
\text { Diet (\%Cal Fat): not reported }\end{array}$ \\
\hline $\begin{array}{l}\text { Stepping STONE } \\
\text { Sheppard et al. (81) }\end{array}$ & $\begin{array}{l}\text { Sample size: } 22 \mathrm{AA} \\
\text { Mean age: } 55 \text { years } \\
\text { Mean BMl: } 36 \mathrm{~kg} / \mathrm{m}^{2} \\
\text { Mean years } \\
\text { post-diagnosis: } 2 \\
\text { years }\end{array}$ & $\begin{array}{l}\text { Randomized to a 12-week multimodal } \\
\text { lifestyle intervention or a general health } \\
\text { information program. } \\
\text { Social Cognitive Theory (SCT) and } \\
\text { Motivational Interviewing }\end{array}$ & $\begin{array}{l}\text { Weight: }-0.8 \text { vs. }+0.2 \% \\
\text { PA (minutes/week): }+160 \text { vs. }+55 \\
\text { Diet (\%Cal Fat): }-4.8 \% \text { vs. not reported }\end{array}$ \\
\hline $\begin{array}{l}\text { Mindful Eating } \\
\text { Chung et al. (90) }\end{array}$ & $\begin{array}{l}\text { Sample size: } 22 \mathrm{AA} \\
\text { Mean age: } 50 \text { years } \\
\text { Mean BMl: } 35 \mathrm{~kg} / \mathrm{m}^{2} \\
\text { Mean years } \\
\text { post-diagnosis: N/A }\end{array}$ & $\begin{array}{l}\text { Single group into a } 24 \text {-week diet and } \\
\text { support group intervention using Cognitive } \\
\text { behavior therapy (CBT) } \\
\text { No stated health promotion theory. }\end{array}$ & $\begin{array}{l}\text { Weight: }-0.5 \%{ }^{*} \\
\text { PA: N/A } \\
\text { Diet (\%Cal Fat): N/A }\end{array}$ \\
\hline $\begin{array}{l}\text { Curves II } \\
\text { Delgado-Cruzata (94) }\end{array}$ & $\begin{array}{l}\text { Sample size: } 24 \\
\text { Hispanic, AA, and } \\
\text { Afro-Caribbean } \\
\text { survivors } \\
\text { Mean age: } 52 \text { years } \\
\text { Mean BMl: } 33 \mathrm{~kg} / \mathrm{m}^{2} \\
\text { Mean years } \\
\text { post-diagnosis: } 3 \\
\text { years }\end{array}$ & $\begin{array}{l}\text { Randomized to a 6-month physical activity } \\
\text { and dietary change intervention or a } \\
\text { waitlist control group. } \\
\text { No stated health promotion theory. }\end{array}$ & $\begin{array}{l}\text { Weight: }-2.0 \%{ }^{*} \\
\text { PA: }+85 \%,{ }^{*} \text { not in a standard format } \\
\text { Diet ( } \% \text { Cal Fat): } 4 \%\end{array}$ \\
\hline $\begin{array}{l}\text { An Active Life } \\
\text { Greenlee et al. (92) }\end{array}$ & $\begin{array}{l}\text { Sample size: } 42 \\
\text { Hispanic, AA, and } \\
\text { Afro-Caribbean } \\
\text { Mean age: } 51 \text { years } \\
\text { Mean BMl: } 33 \mathrm{~kg} / \mathrm{m}^{2} \\
\text { Mean years } \\
\text { post-diagnosis: } 4 \\
\text { years }\end{array}$ & $\begin{array}{l}\text { Randomized to a 6-month physical activity } \\
\text { and dietary change intervention or a } \\
\text { delayed intervention control. } \\
\text { Stages of Change (SOC) }\end{array}$ & $\begin{array}{l}\text { Weight: }-3.3 \text { vs. }-1.8 \%{ }^{*} \\
\text { PA: not in a usable format } \\
\text { Diet (\%Cal Fat): }+0.5 \% \text { vs. }-0.9 \%\end{array}$ \\
\hline $\begin{array}{l}\text { LIFE Study } \\
\text { Djuric et al. (91) }\end{array}$ & $\begin{array}{l}\text { Sample size: } 31 \text { AA } \\
\text { Mean age: } 56 \text { years } \\
\text { Mean BMl: } 36.3 \\
\text { kg/m² } \\
\text { Mean years } \\
\text { post-diagnosis: } 6 \\
\text { years }\end{array}$ & $\begin{array}{l}\text { Randomized to a 6-month dietician-led } \\
\text { counseling, a spiritual counseling } \\
\text { intervention or an unassigned control } \\
\text { group. } \\
\text { Social Cognitive Theory supplemented } \\
\text { with the 12-Steps type curriculum }\end{array}$ & $\begin{array}{l}\text { Weight: }-2.5 \text { vs. }-1.5 \% \\
\text { PA (minutes/week): }+144 \text { vs. } 0 \\
\text { Diet ( } \% \text { Cal Fat): }-7.8 \% \text { vs. }-5.6 \%\end{array}$ \\
\hline $\begin{array}{l}\text { Moving Forward I } \\
\text { Stolley et al. (52) }\end{array}$ & $\begin{array}{l}\text { Sample size: } 23 \mathrm{AA} \\
\text { Mean age: } 51 \text { years } \\
\text { Mean BMl: } 35 \mathrm{~kg} / \mathrm{m}^{2} \\
\text { Mean years } \\
\text { post-diagnosis: N/A }\end{array}$ & $\begin{array}{l}\text { Single group into a 6-month weight loss } \\
\text { intervention targeting dietary intake and } \\
\text { physical activity } \\
\text { Social Cognitive Theory and the Health } \\
\text { Belief Model }\end{array}$ & $\begin{array}{l}\text { Weight: }-2.9 \%{ }^{\star} \\
\text { PA (minutes/week): }+38.9 \text { min/day } \\
\text { Diet (\%Cal Fat): }-3.4 \%\end{array}$ \\
\hline
\end{tabular}

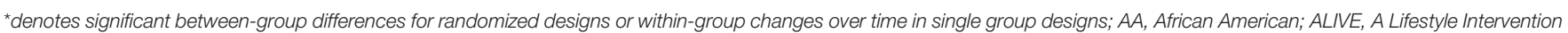

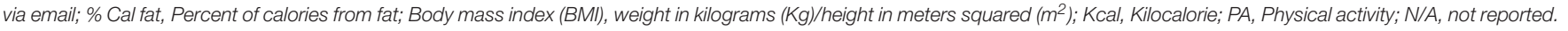

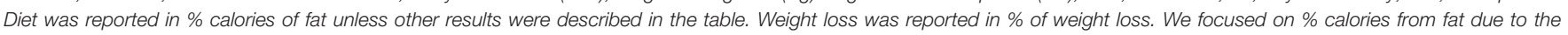
findings from the Women's Intervention Nutrition Study. Outcomes were based on the pre- and post-test assessments and not follow-up assessments. 
TABLE 2 | Identified diet only studies in African American breast cancer survivors.

\begin{tabular}{|c|c|c|c|}
\hline Study & Sample & Intervention & Outcomes \\
\hline $\begin{array}{l}\text { ALIVE}^{\wedge} \\
\text { Paxton et al. (99) }\end{array}$ & $\begin{array}{l}\text { Sample size: } 71 \text { (59 } \\
\text { AABCS) } \\
\text { Mean age: } 52 \text { years } \\
\text { Mean BMl: } 31 \mathrm{~kg} / \mathrm{m}^{2} \\
\text { Mean years post-diagnosis: } \\
8 \text { years }\end{array}$ & $\begin{array}{l}\text { Randomized to a 3-month fully-automatic web- } \\
\text { and email-based dietary or physical activity } \\
\text { Social cognitive theory and goal setting }\end{array}$ & $\begin{array}{l}\text { Weight: N/A } \\
\text { PA (minutes/week): }+49 \text { vs. }+94 \text { min }^{\star} \\
\text { Diet (grams/day): }-1.8 \text { vs. }-0.6 \text { saturated fat grams }\end{array}$ \\
\hline $\begin{array}{l}\text { WINS-C } \\
\text { Griffith et al. (98) }\end{array}$ & $\begin{array}{l}\text { Sample size: } 8 \mathrm{AA} \\
\text { Mean age: } 61 \text { years } \\
\text { Mean BMl: } 31 \mathrm{~kg} / \mathrm{m}^{2} \\
\text { Mean years post-diagnosis: } \\
7 \text { years }\end{array}$ & $\begin{array}{l}\text { Diet only program-Culturally tailored Women's } \\
\text { Intervention Nutrition Study }\end{array}$ & $\begin{array}{l}\text { Weight: N/A } \\
\text { PA: N/A } \\
\text { Diet (\% Cal fat): }-3 \% \text { Cal }\end{array}$ \\
\hline $\begin{array}{l}\text { WHEL Study } \\
\text { Paxton et al. (49) }\end{array}$ & $\begin{array}{l}\text { Sample size: } 118 \mathrm{AA} \\
\text { Mean age: } 50 \\
\text { Mean } \mathrm{BMI}=31 \mathrm{~kg} / \mathrm{m}^{2} \\
\text { Mean years post-diagnosis: } \\
2 \text { years }\end{array}$ & $\begin{array}{l}\text { Participants were randomized to low fat, high } \\
\text { fiber diet vs. a standard national cancer } \\
\text { institute diet. } \\
\text { Social cognitive theory }\end{array}$ & $\begin{array}{l}\text { Weight: }-0.03 \text { vs. }+0.75 \% \\
\text { PA: }+47 \text { vs. }+45 \text { Metabolic equivalent-minutes/week } \\
\text { Diet ( } \% \text { Cal fat): }-4 \% \text { vs. }-1.5 \%{ }^{*}\end{array}$ \\
\hline
\end{tabular}

*denotes significant between-group differences for randomized designs or within-group changes over time in single-group designs; AA, African American; ALIVE, A Lifestyle Intervention via email; \% Cal fat, Percent of calories from fat; Body mass index (BMI), weight in kilograms (Kg)/height in meters squared ( $m^{2}$ ); PA, Physical activity; N/A, not reported; Diet was reported in \% calories of fat unless other results were described in the table. Weight loss was reported in \% of weight loss. We focused on \% calories from fat due to the findings from the Women's Intervention Nutrition Study. Outcomes were based on the pre- and post-test assessments and not follow-up assessments. WHEL, Women's Healthy Eating and Living

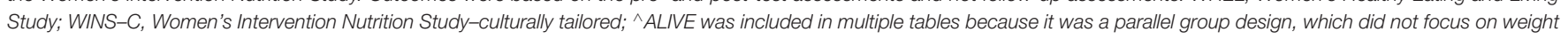
loss as an outcome.

outcomes in various cancer populations (26). The data gathered from these studies will likely clarify the specific durations and frequencies of physical activity that produce desirable outcomes.

\section{Physical activity studies in AA breast cancer survivors}

Despite the push to expand research in the area of physical activity and cancer survivorship, only a few physical activity studies have focused on AA breast cancer survivors. We identified six studies that focused exclusively on improving physical activity (99, 104-108). One of the six studies incorporated diet but used a parallel group design (99), and one used yoga to improve quality of life (108). All studies resulted in significant improvements in physical activity. However, attendance was the outcomes of the yoga intervention. Wilson et al. (106) in an 8-week walking intervention observed significant weight loss. Strategies included using group- or team-based strategies $(106,107)$ or combined group and home-based strategies $(104,105)$. Spector et al. (104), in particular, used a certified personal training to encourage aerobic and resistance training. Paxton et al. (99) used a fully automated web-based program called A Lifestyle Intervention via Email (ALIVE). Improvements in physical activity ranged from $+1.3 \%$ (106) to $+544 \%$ (104). The physical activity studies we identified were reported in Table 3.

\section{Summary of physical activity studies in AA breast cancer survivors}

Intervention studies have been largely successful in improving the physical activity habits of breast cancer survivors. Although few physical activity intervention studies exist for AA breast cancer survivors, they show positive results. Therefore, we can conclude that AA breast cancer survivors are capable of adhering to physical activity interventions that range from traditional home-based interventions to more complex webbased platforms. Future research should consider examining the benefits of strength training interventions in this population as well as the factors that mediate and moderate the relationships between physical activity and psychosocial, behavioral, and physiological outcomes.

\section{Sedentary behaviors}

To our knowledge, few intervention studies have intervened on sedentary time or have observed significant changes in sedentary time. In a web-based study of AA breast cancer survivors, Paxton et al. (99) observed significant reductions in sedentary time. The authors used a web-based platform entitled ALIVE. ALIVE is a fully automated system that uses weekly emails, self-monitoring, and goal-setting tools, and automated phone calls to improve health behaviors. The reduction in sedentary behavior was unexpected, as the ALIVE system targeted physical activity and mentioned SB as a health hazard. These results highlight the potential of a non-intensive or brief interventions to help breast cancer survivors adopt positive health behaviors. The ACTIVity And TEchnology (ACTIVATE) trial (109) will be one of the first to examine the effectiveness of a detailed curriculum to reduce prolonged sitting. The ACTIVATE trial will also incorporate activity trackers for self-monitoring and goal setting purposes. Additional studies that examine the impact of reducing time spent sitting on biological mediators, and cancer-related outcomes are warranted. Future studies should also consider the individual and joint effect of SB and physical activity interventions. 
TABLE 3 | Identified physical activity online intervention studies in African American breast cancer survivors.

\begin{tabular}{|c|c|c|c|}
\hline Study & Sample & Intervention & Outcomes \\
\hline $\begin{array}{l}\text { Team walking } \\
\text { Piacentine et al. (106) }\end{array}$ & $\begin{array}{l}\text { Sample size: } 12 \\
\text { Mean age: } 54 \text { years } \\
\text { Mean BMl: } 34 \text { kg/m² } \\
\text { Mean years } \\
\text { post-diagnosis: N/A }\end{array}$ & $\begin{array}{l}\text { 14-week team-based walking intervention. } \\
\text { Theory of planned behavior }\end{array}$ & $\begin{array}{l}\text { Weight: }+1.1 \% \\
\text { PA (meters): }+67 \text { meters }^{\star} \\
\text { Diet: N/A }\end{array}$ \\
\hline $\begin{array}{l}\text { Home-Based } \\
\text { Spector et al. (104) }\end{array}$ & $\begin{array}{l}\text { Sample size: } 13 \text { AA } \\
\text { Mean age: } 52 \text { years } \\
\text { Mean BMl: } 30 \mathrm{~kg} / \mathrm{m}^{2} \\
\text { Mean years } \\
\text { post-diagnosis: N/A }\end{array}$ & $\begin{array}{l}\text { Single group into a } 16 \text {-week home-based } \\
\text { physical activity intervention. } \\
\text { No stated health promotion theory. }\end{array}$ & $\begin{array}{l}\text { Weight: }-0.3 \% \\
\text { PA (minutes/week): }+212.7^{\star} \\
\text { Diet: not reported }\end{array}$ \\
\hline $\begin{array}{l}\text { Yoga } \\
\text { Moadel et al. (108) }\end{array}$ & $\begin{array}{l}\text { Sample size: } 128,(54 \\
\text { AA) } \\
\text { Mean age: } 55 \text { years } \\
\text { Mean BMl: } 34 \text { kg/m² } \\
\text { Mean years } \\
\text { post-diagnosis: } 1.1\end{array}$ & $\begin{array}{l}\text { Randomized to a 12-week Yoga intervention or } \\
\text { waitlist control condition. } \\
\text { No stated health promotion theory. }\end{array}$ & $\begin{array}{l}\text { Weight: N/A } \\
\text { PA (yoga sessions): } 7 \pm 4 \text { sessions } \\
\text { Diet: N/A }\end{array}$ \\
\hline $\begin{array}{l}\text { Walking Program } \\
\text { Wilson et al. (106) }\end{array}$ & $\begin{array}{l}\text { Sample size: } 22 \text { AA } \\
\text { Mean age: } 55 \text { years } \\
\text { Mean BMl: } 33 \text { kg/m² } \\
\text { Baseline weight: } 191 \\
\text { pounds } \\
\text { Mean years } \\
\text { post-diagnosis: N/A }\end{array}$ & $\begin{array}{l}\text { Single group 8-week walking intervention } \\
\text { Health Belief Model (HBM) }\end{array}$ & $\begin{array}{l}\text { Weight: }-1.1 \%^{*} \\
\text { PA (steps/week): }+3,506 \text { steps }^{*} \\
\text { Diet: N/A }\end{array}$ \\
\hline
\end{tabular}

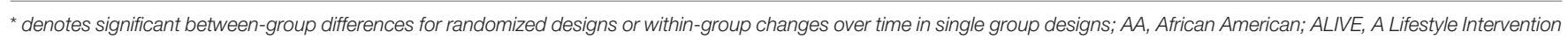

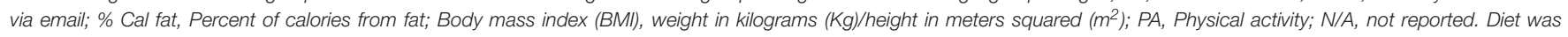

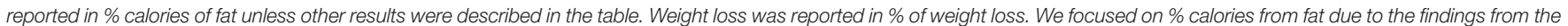

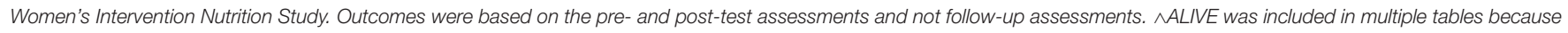
it was a parallel group design, which did not focus on weight loss as an outcome.

\section{Risk of Bias}

A total of 7 interventions studies were characterized as high bias (52, 90, 98, 104-107), 7 studies were characterized a moderate bias $(81,91-94,99,108)$, and 2 studies were characterized a low bias $(49,89)$. Risk of bias was lowest for the weight loss studies and highest for the physical activity studies (see Table 4).

\section{DISCUSSION}

\section{Summary of Main Findings}

Our review indicated that many AA breast cancer survivors failed to meet guidelines for healthy living as indicated by high rates of obesity, poor diet, and physical inactivity. Although many of the studies were rated as having a high or moderate risk of bias, many resulted in significant improvements in health behaviors. The majority of the studies had small samples sizes, which resulted in significant bias. Only two of the studies were rated as having low bias. Notably, Stolley et al. (89) demonstrated that guided community-based trials could be successful in producing significant weight loss. Additional robust randomized trials are needed.

\section{Challenges to and Solutions for Improving Minority-Based Survivorship Research}

Studies have indicated that AA breast cancer survivors experience significant social (e.g., support), environmental (e.g., access, crime, neighborhood cohesion), and personal barriers (e.g., time and interest) that may diminish their ability to engage in recommended levels of activity or consume a healthy diet (110-112). Other challenges such as poor patient-provider 
TABLE 4 | Risk of bias ranking for the identified intervention studies.

\begin{tabular}{|c|c|c|c|c|c|}
\hline Study author, year & Sample & Design & Outcome & Total score & Bias ranking \\
\hline \multicolumn{6}{|l|}{ WEIGHT LOSS } \\
\hline Stolley et al. (89) & $>50$ & Randomized & Objective & 99 & Low bias \\
\hline Valle et al. (93) & $<50$ & Randomized & Objective & 88 & Moderate bias \\
\hline Sheppard et al. (81) & $<30$ & Randomized & Objective & 77 & Moderate bias \\
\hline Chung et al. (90) & $<30$ & Single group & Self-reported & 33 & High bias \\
\hline Delgado-Cruzata et al. (94) & $<30$ & Randomized & Objective & 77 & Moderate bias \\
\hline Greenlee et al. (92) & $<50$ & Randomized & Objective & 88 & Moderate bias \\
\hline Djuric et al. (91) & $<30$ & Randomized & Objective & 88 & Moderate bias \\
\hline Stolley et al. (52) & $<30$ & Single group & Objective & 55 & High bias \\
\hline \multicolumn{6}{|l|}{ DIETARY INTAKE } \\
\hline Paxton et al. (99) & $>50$ & Randomized & Self-reported & 77 & Moderate bias \\
\hline Griffith et al. (98) & $<30$ & Single group & Objective & 55 & High bias \\
\hline Paxton et al. (49) & $>50$ & Randomized & Objective & 99 & Low bias \\
\hline \multicolumn{6}{|l|}{ PHYSICAL ACTIVITY } \\
\hline Piacentine et al. (107) & $<30$ & Single group & Objective & 55 & High bias \\
\hline Paxton et al. (99) & $>50$ & Randomized & Self-reported & 77 & Moderate bias \\
\hline Spector et al. (104) & $<30$ & Single group & Objective & 55 & High bias \\
\hline Nock et al. (105) & $<30$ & Single group & Objective & 55 & High bias \\
\hline Moadel et al. (108) & $>50$ & Randomized & Self-reported & 77 & Moderate bias \\
\hline Wilson et al. (106) & $<30$ & Single group & Objective & 55 & High bias \\
\hline
\end{tabular}

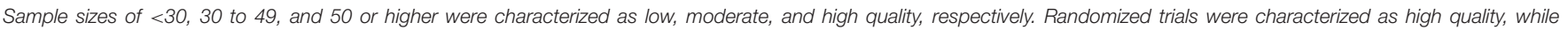

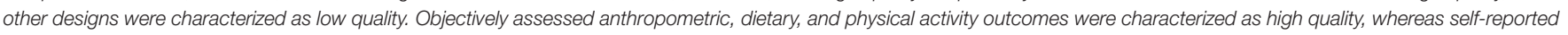

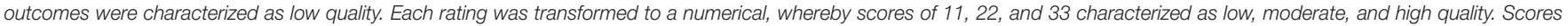
were summed across categories. Total scores of <60, 60 to <99, and 99 were characterized as high, moderate, and low bias studies.

communication and that the failure of physicians to provide equitable care often contributes to mistrust among AA breast cancer survivors $(113,114)$. Comprehensive strategies that reach AA breast cancer survivors where they are and provide evidencebased strategies may help to reduce their actual and perceived barriers. AA women may also benefit from removing themselves from environments and people that are not supportive of their desired lifestyle changes.

Demark-Wahnefried et al. (26) recommended collaborating with community-based organizations, utilizing local farmer's markets, and promoting the 5-A's (Ask, Advise, Assess, Assist, and Arrange) in a clinical setting as potential strategies to reduce health-related barriers. In AA communities, efforts can be made to leverage churches, civic organizations, parks, and recreation centers to provide support systems and venues for programmatic activities. Expanding upon models such as Body and Soul $(115,116)$ may also hold promise in promoting physical activity and weight-management in community-based settings. Similar efforts are underway in underserved populations in Hawaii (117). These efforts are promising because they incorporate traditional foods and spirituality to encourage behavior change. In addition, reducing prolonged sitting or breaking up sedentary time may be a low hanging fruit $(78,118,119)$. Capitalizing on concepts such as "tiny habits" proposed by BJ Fogg at Stanford University may also provide sufficient motivation to make long-lasting behavioral changes (120). Furthermore, focusing on enjoyable activities such as gardening (121), dancing (122), and acquiring extra steps while shopping may be additional strategies to promote.

\section{The Need for Comprehensive and Personalized Approaches}

Literature documenting the dietary habits of AA breast cancer survivors has been limited to single nutrient analyses (e.g., fruit and vegetable consumption and dietary fat intake). Single nutrient analyses may be sufficient for understanding what nutrients are needed, but not sufficient for describing overall dietary patterns or diet quality. Investigators have been studying dietary patterns and diet quality indexes as a means to summarize entire diets rather than single nutrients (123-125). Researchers interested in understanding the role that diet plays in the overall health and well-being of AA breast cancer survivors should consider applying similar techniques. Studies conducted in primarily NHW samples have indicated that a prudent diet (i.e., colorful fruits \& vegetables, whole grains, nuts, and cereals) rather than a Western diet (i.e., red and processed meats, foods high in fat and sugar, and refined grains) was associated with overall survival in cancer survivors (47). Large-scale and randomized controlled studies are needed to determine whether dietary patterns or indices influence the health of AA breast cancer survivors (24).

Similarly, additional studies are warranted to determine whether AA breast cancer survivors may benefit more from 
different physical activity frequencies, intensities, types, and durations. There may also be a need for physical activity interventions that are more personalized $(126,127)$. Jones et al. (127) indicated that exercise prescription often adopts a one-size-fits-all approach, which may not be ideal for AA breast cancer survivors whom frequently indicate significant perceived and actual barriers to physical activity $(110,111)$. AA breast cancer survivors are often not interested in or motivated enough to engage in regular physical activity. Interventions that take into account the individual preferences of AA women are needed.

\section{The Potential for Internet and Other Web-Based Platforms}

We identified two studies that used web-based approaches. Both had significant strengths and weaknesses. ALIVE was plagued with functionality challenges that lowered adherence rates (99), whereas the WELL Body study was not powered adequately to detect differences between conditions (93). Despite the limitations of these studies, technology-enhanced approaches offer some advantages, including the opportunity for individual tailoring, elimination of barriers (i.e., cost, time, people, distance); and sustained motivation and feedback for extended periods (128). We would be remiss if we did not indicate the limitations of web-based approaches. The digital divide (i.e., computer literacy and internet access) still exist by race and socioeconomic position, and access to the internet is still less stable for racial/ethnic minorities as well as rural populations (129). Additionally, those who are financially stable may experience periods of economic insecurity attributable to their health status $(130,131)$; these occurrences may not allow them to participate fully and interventions that rely on webbased technologies like Wi-Fi connections. Thus, researchers that rely on smartphones and their related apps may be able to overcome some of these technological disparities, but may encounter other phone-related challenges (i.e., data, screen size, vision, etc.).

\section{Opportunities for Analytical Advancements}

There are new frontiers that should be explored to advance the field of cancer survivorship (132). Questions remain in the areas of identifying (a) effect modifiers, (b) subpopulations that respond differently, and (c) identifying the optimal physical activity prescription and dietary patterns. The questions proposed by Courneya et al. (132) can be expanded to include specific dietary components and interactions that exist among multiple lifestyle behaviors, sociodemographic, and medical characteristics. Techniques such as Random Forest (133) are capable of analyzing high dimensional data with small sample sizes. Others have applied similar techniques to study PA patterns (134). Other intuitive methods such as clustering and recursive partitioning are capable of identifying subgroups with similar behavioral patterns $(135,136)$. Paxton et al. (137) utilized recursive partitioning to examine correlates of physical activity in AA breast cancer survivors. This approach can be expanded to include time to event outcomes.

\section{LIMITATIONS}

In this review, we conducted a comprehensive search to identify peer-reviewed articles. However, we did not select unpublished dissertations and theses or published peer-reviewed abstracts related to our search terms. In addition, we excluded articles they were not seminal in the field of cancer survivorship as well as many articles that focused primarily on psychosocial outcomes. Furthermore, many of the intervention studies we identified were rated as having high or moderate levels of bias. Larger studies are needed to confirm the strategies applied in several studies. Despite our limitations, we found no similar reviews to compare our findings. Thus, this study represents a unique contribution to the literature.

\section{CONCLUSION}

Our review provides objective information identifying the strengths, weaknesses, and opportunities that exist for designing lifestyle interventions and epidemiological studies for AA breast cancer survivors. AA breast cancer survivors, like other vulnerable cancer populations, are often difficult to track and trace. Therefore, innovative strategies are needed to recruit and retain them in randomized trials. Leveraging partnerships with community-based organizations, support groups, and health systems may help to identify sufficient numbers to support a clinical trial. Studies are warranted that examine the impact of lifestyle behaviors in individuals with multiple comorbid conditions, as many minority survivors are predisposed to higher rates of diabetes and cardiovascular disease when compared to other ethnic groups. Lastly, reducing sedentary behavior represents a "tiny habit" that may result in sustainable changes in physical activity over time.

\section{AUTHOR CONTRIBUTIONS}

RP conceived the study. WG and GL reviewed and summarized intervention studies and created tables. RP, WG, GL, LD, and KA-W drafted and edited versions of the manuscript.

\section{FUNDING}

RP was supported by National Cancer Institute grant K01CA 158000 and funds provided by the University of Alabama. LD was supported by the National Cancer Institute (K01CA184288); the Sidney Kimmel Cancer Center grants P30CA006973; Johns Hopkins University Center for AIDS Research grant P30AI094189, and the National Institute of Mental Health grant R25MH083620.

\section{ACKNOWLEDGMENTS}

We want to the thank the scientists who have contributed to the body of work designed to understand the health and well-being of AA breast cancers survivors. 


\section{REFERENCES}

1. Smith BD, Smith GL, Hurria A, Hortobagyi GN, Buchholz TA. Future of cancer incidence in the United States: burdens upon an aging, changing nation. J Clin Oncol. (2009) 27:2758-65. doi: 10.1200/JCO.2008.20.8983

2. Calip GS, Law EH, Ko NY. Racial and ethnic differences in risk of second primary cancers among breast cancer survivors. Breast Cancer Res Treat. (2015) 151:687-96. doi: 10.1007/s10549-015-3439-7

3. Newman LA, Kaljee LM. Health disparities and triple-negative breast cancer in african american women: a review. JAMA Surg. (2017) 152:485-93. doi: 10.1001/jamasurg.2017.0005

4. Jiagge E, Jibril AS, Chitale D, Bensenhaver JM, Awuah B, Hoenerhoff M, et al. Comparative analysis of breast cancer phenotypes in african american, white american, and west versus east african patients: correlation between african ancestry and triple-negative breast cancer. Ann Surg Oncol. (2016) 23:3843-9. doi: 10.1245/s10434-016-5420-z

5. Llanos AA, Chandwani S, Bandera EV, Hirshfield KM, Lin Y, Ambrosone CB, et al. Associations between sociodemographic and clinicopathological factors and breast cancer subtypes in a population-based study. Cancer Causes Control. (2015) 26:1737-50. doi: 10.1007/s10552-015-0667-4

6. Sturtz LA, Melley J, Mamula K, Shriver CD, Ellsworth RE. Outcome disparities in African American women with triple negative breast cancer: a comparison of epidemiological and molecular factors between African American and Caucasian women with triple negative breast cancer. $B M C$ Cancer (2014) 14:62. doi: 10.1186/1471-2407-14-62

7. Bianchini G, Balko JM, Mayer IA, Sanders ME, Gianni L. Triple-negative breast cancer: challenges and opportunities of a heterogeneous disease. Nat Rev Clin Oncol. (2016) 13:674-90. doi: 10.1038/nrclinonc.2016.66

8. Newman LA, Bunner S, Carolin K, Bouwman D, Kosir MA, White M, et al. Ethnicity related differences in the survival of young breast carcinoma patients. Cancer (2002) 95:21-7. doi: 10.1002/cncr.10639

9. Shavers VL, Harlan LC, Stevens JL. Racial/ethnic variation in clinical presentation, treatment, and survival among breast cancer patients under age 35. Cancer (2003) 97:134-47. doi: 10.1002/cncr.11051

10. Triple-negative breast cancer rate is triply high in black women. Harv Womens Health Watch (2009) 16:7. doi: 10.1038/nrc3896

11. Anders CK, Carey LA. Biology, metastatic patterns, and treatment of patients with triple-negative breast cancer. Clin Breast Cancer (2009) 9(Suppl. 2):S7381. doi: 10.3816/CBC.2009.s.008

12. Balmanoukian A, Zhang Z, Jeter S, Slater S, Armstrong DK, Emens LA, et al. African American women who receive primary anthracycline- and taxanebased chemotherapy for triple-negative breast cancer suffer worse outcomes compared with white women. J Clin Oncol. (2009) 27:e35-7; author reply e38-9. doi: 10.1200/JCO.2008.21.5509

13. Huo D, Ikpatt F, Khramtsov A, Dangou JM, Nanda R, Dignam J, et al. Population differences in breast cancer: survey in indigenous African women reveals over-representation of triple-negative breast cancer. J Clin Oncol. (2009) 27:4515-21. doi: 10.1200/JCO.2008.19.6873

14. Kwan ML, Kushi LH, Weltzien E, Maring B, Kutner SE, Fulton RS, et al. Epidemiology of breast cancer subtypes in two prospective cohort studies of breast cancer survivors. Breast Cancer Res. (2009) 11:R31. doi: $10.1186 / \mathrm{bcr} 2261$

15. Lund MJ, Trivers KF, Porter PL, Coates RJ, Leyland-Jones B, Brawley OW, et al. Race and triple negative threats to breast cancer survival: a populationbased study in Atlanta, GA. Breast Cancer Res Treat. (2009) 113:357-70. doi: 10.1007/s10549-008-9926-3

16. Parise CA, Bauer KR, Caggiano V. Variation in breast cancer subtypes with age and race/ethnicity. Crit Rev Oncol Hematol. (2009) 76:44-52. doi: 10.1016/j.critrevonc.2009.09.002

17. Stead LA, Lash TL, Sobieraj JE, Chi DD, Westrup JL, Charlot M, et al. Triplenegative breast cancers are increased in black women regardless of age or body mass index. Breast Cancer Res. (2009) 11:R18. doi: 10.1186/bcr2242

18. Williams DR, Mohammed SA, Shields AE. Understanding and effectively addressing breast cancer in African American women: unpacking the social context. Cancer (2016) 122:2138-49. doi: 10.1002/cncr.29935

19. Krieger N, Jahn JL, Waterman PD. Jim Crow and estrogen-receptor-negative breast cancer: US-born black and white non-Hispanic women, 1992-2012. Cancer Causes Control. (2017) 28:49-59. doi: 10.1007/s10552-016-0834-2
20. Krieger N, Jahn JL, Waterman PD, Chen JT. Breast cancer estrogen receptor by biological generation: US black \& white women, born 1915-1979. Am J Epidemiol. (2017) 87:960-70. doi: 10.1093/aje/kwx312

21. Hunt BR, Hurlbert MS. Black:white disparities in breast cancer mortality in the 50 largest cities in the United States, 2005-2014. Cancer Epidemiol. (2016) 45 169-73. doi: 10.1016/j.canep.2016.07.018

22. Tammemagi CM, Nerenz D, Neslund-Dudas C, Feldkamp C, Nathanson D. Comorbidity and survival disparities among black and white patients with breast cancer. JAMA (2005) 294:1765-72. doi: 10.1001/jama.294.14.1765

23. Swartz MC, Lewis ZH, Lyons EJ, Jennings $\mathrm{K}$, Middleton A, Deer RR, et al. Effect of home- and community-based physical activity interventions on physical function among cancer survivors: a systematic review and meta-analysis. Arch Phys Med Rehabil. (2017) 98:1652-65. doi: 10.1016/j.apmr.2017.03.017

24. Jochems SHJ, Van Osch FHM, Bryan RT, Wesselius A, van Schooten FJ, Cheng KK, et al. Impact of dietary patterns and the main food groups on mortality and recurrence in cancer survivors: a systematic review of current epidemiological literature. BMJ Open (2018) 8:e014530. doi: 10.1136/bmjopen-2016-014530

25. Fairman CM, Focht BC, Lucas AR, Lustberg MB. Effects of exercise interventions during different treatments in breast cancer. $J$ Community Support Oncol. (2016) 14:200-9. doi: 10.12788/jcso.0225

26. Demark-Wahnefried W, Schmitz KH, Alfano CM, Bail JR, Goodwin $\mathrm{PJ}$, Thomson CA, et al. Weight management and physical activity throughout the cancer care continuum. CA Cancer J Clin. (2018) 68:64-89. doi: $10.3322 /$ caac. 21441

27. Chandler J, Higgins JPT, Deeks JJ, Davenport C, Clarke MJ. Chapter 1: Introduction. In: Higgins JPT, Churchill R, Chandler J, Cumpston MS editors. Cochrane Handbook for Systematic Reviews of Interventions Version 5.2.0 (Updated February 2017), London: Cochrane 2017.

28. Rose DP, Haffner SM, Baillargeon J. Adiposity, the metabolic syndrome, and breast cancer in African-American and white American women. Endocr Rev (2007) 28:763-77. doi: 10.1210/er.2006-0019

29. Vona-Davis L, Howard-McNatt M, Rose DP. Adiposity, type 2 diabetes and the metabolic syndrome in breast cancer. Obes Rev. (2007) 8:395-408. doi: 10.1111/j.1467-789X.2007.00396.x

30. Bertrand KA, Bethea TN, Adams-Campbell LL, Rosenberg L, Palmer JR. Differential patterns of risk factors for early-onset breast cancer by ER status in African American women. Cancer Epidemiol Biomarkers Prev. (2017) 26:270-77. doi: 10.1158/1055-9965.EPI-16-0692

31. Kerlikowske K, Gard CC, Tice JA, Ziv E, Cummings SR, Miglioretti DL, et al. Risk factors that increase risk of estrogen receptor-positive and -negative breast cancer. J Natl Cancer Inst. (2017) 109:10. doi: 10.1093/jnci/djw276

32. Sun H, Zou J, Chen L, Zu X, Wen G, Zhong J. Triple-negative breast cancer and its association with obesity. Mol Clin Oncol. (2017) 7:935-42. doi: $10.3892 /$ mco.2017.1429

33. Dietze EC, Chavez TA, Seewaldt VL. Obesity and triple-negative breast cancer: disparities, controversies, and biology. Am J Pathol. (2018) 188:28090. doi: 10.1016/j.ajpath.2017.09.018

34. Nayak P, Paxton RJ, Holmes H, Thanh Nguyen H, Elting LS. Racial and ethnic differences in health behaviors among cancer survivors. Am J Prev Med. (2015) 48:729-36. doi: 10.1016/j.amepre.2014. 12.015

35. Paxton RJ, Phillips KL, Jones LA, Chang S, Taylor WC, Courneya KS, et al. Associations among physical activity, body mass index, and health-related quality of life by race/ethnicity in a diverse sample of breast cancer survivors. Cancer (2012) 118:4024-31. doi: 10.1002/cncr.27389

36. Smith AW, Alfano CM, Reeve BB, Irwin ML, Bernstein L, Baumgartner $\mathrm{K}$, et al. Race/ethnicity, physical activity, and quality of life in breast cancer survivors. Cancer Epidemiol Biomarkers Prev. (2009) 18:656-63. doi: 10.1158/1055-9965.EPI-08-0352

37. Rock CL, Flatt SW, Newman V, Caan BJ, Haan MN, Stefanick ML, et al. Factors associated with weight gain in women after diagnosis of breast cancer. Women's Healthy Eating and Living Study Group. J Am Diet Assoc. (1999) 99:1212-21. doi: 10.1016/S0002-8223(99) 00298-9

38. Grann V, Troxel AB, Zojwalla N, Hershman D, Glied SA, Jacobson JS. Regional and racial disparities in breast cancer-specific mortality. 
Soc Sci Med. (2006) 62:337-47. doi: 10.1016/j.socscimed.2005. 06.038

39. Jones BA, Kasi SV, Curnen MG, Owens PH, Dubrow R. Severe obesity as an explanatory factor for the black/white difference in stage at diagnosis of breast cancer. Am J Epidemiol. (1997) 146:394-404.

40. Soler-Vila H, Kasl SV, Jones BA. Prognostic significance of psychosocial factors in African-American and white breast cancer patients: a populationbased study. Cancer (2003) 98:1299-308. doi: 10.1002/cncr.11670

41. Nichols HB, Trentham-Dietz A, Egan KM, Titus-Ernstoff L, Holmes $\mathrm{MD}$, Bersch AJ, et al. Body mass index before and after breast cancer diagnosis: associations with all-cause, breast cancer, and cardiovascular disease mortality. Cancer Epidemiol Biomarkers Prev. (2009) 18:1403-9. doi: 10.1158/1055-9965.EPI-08-1094

42. Guenancia C, Lefebvre A, Cardinale D, Yu AF, Ladoire S, Ghiringhelli F, et al. Obesity as a risk factor for anthracyclines and trastuzumab cardiotoxicity in breast cancer: a systematic review and meta-analysis. J Clin Oncol. (2016) 34:3157-65. doi: 10.1200/JCO.2016.67.4846

43. Chan DS, Vieira AR, Aune D, Bandera EV, Greenwood DC, McTiernan A, et al. Body mass index and survival in women with breast cancer-systematic literature review and meta-analysis of 82 follow-up studies. Ann Oncol. (2014) 25:1901-14. doi: 10.1093/annonc/mdu042

44. Rock CL, Doyle C, Demark-Wahnefried W, Meyerhardt J, Courneya KS, Schwartz AL, et al. Nutrition and physical activity guidelines for cancer survivors. CA Cancer J Clin. (2012) 62:243-74. doi: 10.3322/caac.21142

45. Balter K, Moller E, Fondell E. The effect of dietary guidelines on cancer risk and mortality. Curr Opin Oncol. (2012) 24:90-102. doi: 10.1097/CCO.0b013e32834e0531

46. Kroenke $\mathrm{CH}$, Fung TT, Hu FB, Holmes MD. Dietary patterns and survival after breast cancer diagnosis. J Clin Oncol. (2005) 23:9295-303. doi: 10.1200/JCO.2005.02.0198

47. Kwan ML, Weltzien E, Kushi LH, Castillo A, Slattery ML, Caan BJ. Dietary patterns and breast cancer recurrence and survival among women with early-stage breast cancer. J Clin Oncol. (2009) 27:919-26. doi: 10.1200/JCO.2008.19.4035

48. Vrieling A, Buck K, Seibold P, Heinz J, Obi N, Flesch-Janys D, et al. Dietary patterns and survival in German postmenopausal breast cancer survivors. $\mathrm{Br}$ J Cancer (2013) 108:188-92. doi: 10.1038/bjc.2012.521

49. Paxton RJ, Jones LA, Chang S, Hernandez M, Hajek RA, Flatt SW, et al. Was race a factor in the outcomes of the Women's Health Eating and Living Study? Cancer (2011) 117:3805-13. doi: 10.1002/cncr.25957

50. Ramirez LA, Chung Y, Wonsuk Y, Fontenot B, Ansa BE. Whitehead MS, et al. Determinants of adherence to nutrition-related cancer prevention guidelines among African American breast cancer survivors. J Ga Public Health Assoc. (2016) 6(2 Suppl.):210-22. doi: 10.21633/jgpha.6.2s06

51. Dennis Parker EA, Sheppard VB, Adams-Campbell L. Compliance with national nutrition recommendations among breast cancer survivors in "stepping stone". Integr Cancer Ther. (2014) 13:114-20. doi: 10.1177/1534735413503550

52. Stolley MR, Sharp LK, Oh A, Schiffer L. A weight loss intervention for African American breast cancer survivors, 2006. Prev Chronic Dis. (2009) 6:A22.

53. Doyle C, Kushi LH, Byers T, Courneya KS, Demark-Wahnefried W, Grant $B$, et al. Nutrition and physical activity during and after cancer treatment: an American Cancer Society guide for informed choices. CA Cancer J Clin. (2006) 56:323-53. doi: 10.3322/canjclin.56.6.323

54. Speck RM, Courneya KS, Masse LC, Duval S, Schmitz KH. An update of controlled physical activity trials in cancer survivors: a systematic review and meta-analysis. J Cancer Surviv. 4:87-100. doi: 10.1007/s11764-009-0110-5

55. Schmitz KH, Holtzman J, Courneya KS, Masse LC, Duval S, Kane R. Controlled physical activity trials in cancer survivors: a systematic review and meta-analysis. Cancer Epidemiol Biomarkers Prev. (2005) 14:1588-95. doi: 10.1158/1055-9965.EPI-04-0703

56. Holick CN, Newcomb PA, Trentham-Dietz A, Titus-Ernstoff L, Bersch AJ, Stampfer MJ, et al. Physical activity and survival after diagnosis of invasive breast cancer. Cancer Epidemiol Biomarkers Prev. (2008) 17:379-86. doi: 10.1158/1055-9965.EPI-07-0771

57. Holmes MD, Chen WY, Feskanich D, Kroenke CH, Colditz GA. Physical activity and survival after breast cancer diagnosis. JAMA (2005) 293:2479-86. doi: 10.1001/jama.293.20.2479
58. McNeely ML, Campbell KL, Rowe BH, Klassen TP, Mackey JR, Courneya KS. Effects of exercise on breast cancer patients and survivors: a systematic review and meta-analysis. Cmaj (2006) 175:34-41. doi: 10.1503/cmaj.051073

59. Bertram LA, Stefanick ML, Saquib N, Natarajan L, Patterson RE, Bardwell W, et al. Physical activity, additional breast cancer events, and mortality among early-stage breast cancer survivors: findings from the WHEL Study. Cancer Causes Control. (2010) 22:427-35. doi: 10.1007/s10552-010-9714-3

60. Irwin ML, Smith AW, McTiernan A, Ballard-Barbash R, Cronin K, Gilliland $\mathrm{FD}$, et al. Influence of pre- and postdiagnosis physical activity on mortality in breast cancer survivors: the health, eating, activity, and lifestyle study. J Clin Oncol. (2008) 26:3958-64. doi: 10.1200/JCO.2007.15.9822

61. Cheema B, Gaul CA, Lane K, Fiatarone Singh MA. Progressive resistance training in breast cancer: a systematic review of clinical trials. Breast Cancer Res Treat. (2008) 109:9-26. doi: 10.1007/s10549-007-9638-0

62. Schmitz KH, Ahmed RL, Hannan PJ, Yee D. Safety and efficacy of weight training in recent breast cancer survivors to alter body composition, insulin, insulin-like growth factor axis proteins. Cancer Epidemiol Biomarkers Prev. (2005) 14:1672-80. doi: 10.1158/1055-9965.EPI-04-0736

63. Schmitz KH, Speck RM. Risks and benefits of physical activity among breast cancer survivors who have completed treatment. Womens Health (Lond Engl) 6:221-38. doi: 10.2217/whe.10.1

64. Irwin ML, McTiernan A, Bernstein L, Gilliland FD, Baumgartner R, Baumgartner K, et al. Physical activity levels among breast cancer survivors. Med Sci Sports Exerc. (2004) 36:1484-91.

65. Smith SA, Ansa BE, Yoo W, Whitehead MS, Coughlin SS. Determinants of adherence to physical activity guidelines among overweight and obese African American breast cancer survivors: implications for an intervention approach. Ethn Health (2018) 23:194-206. doi: 10.1080/13557858.2016.1256376

66. Paxton RJ, Taylor WC, Chang S, Courneya KS, Jones LA. Lifestyle behaviors of African American breast cancer survivors: a Sisters Network, Inc. study. PLoS ONE (2013) 8:e61854. doi: 10.1371/journal.pone.0061854

67. Miller AM, Ashing KT, Modeste NN, Herring RP, Sealy DA. Contextual factors influencing health-related quality of life in African American and Latina breast cancer survivors. J Cancer Surviv. (2015) 9:441-9. doi: 10.1007/s11764-014-0420-0

68. Diggins AD, Hearn LE, Lechner SC, Annane D, Antoni MH, Whitehead NE. Physical activity in Black breast cancer survivors: implications for quality of life and mood at baseline and 6-month follow-up. Psychooncology (2017) 26:822-8. doi: 10.1002/pon.4095

69. Sedentary Behaviour Research N. Letter to the editor: standardized use of the terms "sedentary" and "sedentary behaviours". Appl Physiol Nutr Metab. (2012) 37:540-2. doi: 10.1139/h2012-024

70. Salmon J, Owen N, Crawford D, Bauman A, Sallis JF. Physical activity and sedentary behavior: a population-based study of barriers, enjoyment, and preference. Health Psychol. (2003) 22:178-88. doi: 10.1037/0278-6133.22.2.178

71. Dunstan DW, Howard B, Healy GN, Owen N. Too much sittinga health hazard. Diabetes Res Clin Pract. (2012) 97:368-76. doi: 10.1016/j.diabres.2012.05.020

72. Lynch BM, Dunstan DW, Vallance JK, Owen N. Don't take cancer sitting down: a new survivorship research agenda. Cancer (2013) 119:1928-35. doi: $10.1002 /$ cncr. 28028

73. Owen N, Healy GN, Matthews CE, Dunstan DW. Too much sitting: the population health science of sedentary behavior. Exerc Sport Sci Rev. (2010) 38:105-13. doi: 10.1097/JES.0b013e3181e373a2

74. Owen N, Sparling PB, Healy GN, Dunstan DW, Matthews CE. Sedentary behavior: emerging evidence for a new health risk. Mayo Clin Proc. (2010) 85:1138-41. doi: 10.4065/mcp.2010.0444

75. Thorp AA, Healy GN, Owen N, Salmon J, Ball K, Shaw JE, et al. Deleterious associations of sitting time and television viewing time with cardiometabolic risk biomarkers: Australian Diabetes, Obesity and Lifestyle (AusDiab) study 2004-2005. Diabetes Care (2010) 33:327-34. doi: 10.2337/dc09-0493

76. Phillips SM, Awick EA, Conroy DE, Pellegrini CA, Mailey EL, McAuley E. Objectively measured physical activity and sedentary behavior and quality of life indicators in survivors of breast cancer. Cancer (2015) 121:4044-52. doi: $10.1002 / \mathrm{cncr} .29620$

77. George SM, Alfano CM, Wilder Smith A, Irwin ML, McTiernan A, Bernstein L, et al. Sedentary behavior, health-related quality of life, and 
fatigue among breast cancer survivors. J Phys Act Health (2013) 10:350-8. doi: 10.1123/jpah.10.3.350

78. Paxton RJ, Anderson A, Sarkar S, Taylor WC. Breaking up sedentary behavior: perceptions from cancer survivors. Cancer Nurs. (2016) 39:272-8. doi: 10.1097/NCC.0000000000000330

79. Goodwin PJ, Segal RJ, Vallis M, Ligibel JA, Pond GR, Robidoux A, et al. Randomized trial of a telephone-based weight loss intervention in postmenopausal women with breast cancer receiving letrozole: the LISA trial. J Clin Oncol. (2014) 32:2231-9. doi: 10.1200/JCO.2013.53.1517

80. Rock CL, Flatt SW, Byers TE, Colditz GA, Demark-Wahnefried W, Ganz $\mathrm{PA}$, et al. Results of the exercise and nutrition to enhance recovery and good health for you (ENERGY) trial: a behavioral weight loss intervention in overweight or obese breast cancer survivors. J Clin Oncol. (2015) 33:3169-76. doi: 10.1200/JCO.2015.61.1095

81. Sheppard VB, Hicks J, Makambi K, Hurtado-de-Mendoza A, DemarkWahnefried W, Adams-Campbell L. The feasibility and acceptability of a diet and exercise trial in overweight and obese black breast cancer survivors: the Stepping STONE study. Contemp Clin Trials. (2016) 46 106-113. doi: 10.1016/j.cct.2015.12.005

82. Demark-Wahnefried W, Jones LW, Snyder DC, Sloane RJ, Kimmick GG, Hughes DC, et al. Daughters and mothers against breast cancer (DAMES): main outcomes of a randomized controlled trial of weight loss in overweight mothers with breast cancer and their overweight daughters. Cancer (2014) 120:2522-34. doi: 10.1002/cncr.28761

83. Swisher AK, Abraham J, Bonner D, Gilleland D, Hobbs G, Kurian S, et al. Exercise and dietary advice intervention for survivors of triplenegative breast cancer: effects on body fat, physical function, quality of life, and adipokine profile. Support Care Cancer (2015) 23:2995-3003. doi: 10.1007/s00520-015-2667-z

84. Harrigan M, Cartmel B, Loftfield E, Sanft T, Chagpar AB, Zhou Y, et al. Randomized Trial comparing telephone versus in-person weight loss counseling on body composition and circulating biomarkers in women treated for breast cancer: the lifestyle, exercise, and nutrition (LEAN) study. J Clin Oncol. (2016) 34:669-76. doi: 10.1200/JCO.2015.61.6375

85. Villarini A, Pasanisi P, Traina A, Mano MP, Bonanni B, Panico S, et al. Lifestyle and breast cancer recurrences: the DIANA-5 trial. Tumori (2012) 98:1-18. doi: 10.1177/030089161209800101

86. Rack B, Andergassen U, Neugebauer J, Salmen J, Hepp P, Sommer H, et al. The German SUCCESS C Study-The First European lifestyle study on breast cancer. Breast Care (Basel) (2010) 5:395-400. doi: 10.1159/000322677

87. Pegington M, Adams JE, Bundred NJ, Campbell AM, Howell A, Howell SJ, et al. Recruitment to the "Breast-Activity and Healthy Eating After Diagnosis" (B-AHEAD) randomized controlled trial. Integr Cancer Ther. (2018) 17:131-7. doi: 10.1177/1534735416687850

88. Chlebowski RT, Reeves MM. Weight loss randomized intervention trials in female cancer survivors. J Clin Oncol. (2016) 34:4238-48. doi: 10.1200/JCO.2016.69.4026

89. Stolley M, Sheean P, Gerber B, Arroyo C, Schiffer L, Banerjee A, et al. Efficacy of a weight loss intervention for African American breast cancer survivors. J Clin Oncol. (2017) 35:2820-8. doi: 10.1200/JCO.2016.71.9856

90. Chung S, Zhu S, Friedmann E, Kelleher C, Kozlovsky A, Macfarlane KW, et al. Weight loss with mindful eating in African American women following treatment for breast cancer: a longitudinal study. Support Care Cancer (2016) 24:1875-81. doi: 10.1007/s00520-015-2984-2

91. Djuric Z, Mirasolo J, Kimbrough L, Brown DR, Heilbrun LK, Canar L, et al. A pilot trial of spirituality counseling for weight loss maintenance in African American breast cancer survivors. J Natl Med Assoc. (2009) 101:552-64. doi: 10.1016/S0027-9684(15)30940-8

92. Greenlee HA, Crew KD, Mata JM, McKinley PS, Rundle AG, Zhang W, et al. A pilot randomized controlled trial of a commercial diet and exercise weight loss program in minority breast cancer survivors. Obesity (Silver Spring) (2013) 21:65-76. doi: 10.1002/oby.20245

93. Valle C, Deal A, Tate D, Valle CG, Deal AM, Tate DF. Preventing weight gain in African American breast cancer survivors using smart scales and activity trackers: a randomized controlled pilot study. J Cancer Surviv. (2017) 11:133-148. doi: 10.1007/s11764-016-0571-2

94. Delgado-Cruzata L, Zhang W, McDonald JA, Tsai WY, Valdovinos C, Falci L, et al. Dietary modifications, weight loss, and changes in metabolic markers affect global DNA methylation in Hispanic, African American, and Afro-Caribbean breast cancer survivors. J Nutr. (2015) 145:783-90. doi: $10.3945 /$ jn.114.202853

95. Chlebowski RT, Blackburn GL, Thomson CA, Nixon DW, Shapiro A, Hoy $\mathrm{MK}$, et al. Dietary fat reduction and breast cancer outcome: interim efficacy results from the Women's intervention nutrition study. J Natl Cancer Inst. (2006) 98:1767-76. doi: 10.1093/jnci/djj494

96. Pierce JP, Stefanick ML, Flatt SW, Natarajan L, Sternfeld B, Madlensky L, et al. Greater survival after breast cancer in physically active women with high vegetable-fruit intake regardless of obesity. J Clin Oncol. (2007) 25:2345-51. doi: 10.1200/JCO.2006.08.6819

97. Thomson CA, Rock CL, Thompson PA, Caan BJ, Cussler E, Flatt SW, et al. Vegetable intake is associated with reduced breast cancer recurrence in tamoxifen users: a secondary analysis from the Women's Healthy Eating and Living Study. Breast Cancer Res Treat. (2011) 125:519-27. doi: 10.1007/s10549-010-1014-9

98. Griffith KA, Royak-Schaler R, Nesbitt K, Zhan M, Kozlovsky A, Hurley K, et al. A culturally specific dietary plan to manage weight gain among African American breast cancer survivors: a feasibility study. Nutr Health (2012) 21:97-105. doi: 10.1177/0260106012459938

99. Paxton RJ, Hajek R, Newcomb P, Dobhal M, Borra S, Taylor WC, et al. A Lifestyle Intervention via email in minority breast cancer survivors: randomized parallel-group feasibility study. JMIR Cancer (2017) 3:e13. doi: 10.2196/cancer.7495

100. van Meer S, Leufkens AM, Bueno-de-Mesquita HB, van Duijnhoven FJ, van Oijen MG, Siersema PD. Role of dietary factors in survival and mortality in colorectal cancer: a systematic review. Nutr Rev. (2013) 71:631-41. doi: $10.1111 /$ nure. 12042

101. Lofano K, Principi M, Scavo MP, Pricci M, Ierardi E, Di Leo A. Dietary lifestyle and colorectal cancer onset, recurrence, and survival: myth or reality? J Gastrointestinal Cancer (2013) 44:1-11. doi: 10.1007/s12029-012-9425-y

102. McTiernan A, Irwin M, Vongruenigen V. Weight, physical activity, diet, and prognosis in breast and gynecologic cancers. J Clin Oncol. (2010) 28:4074-80. doi: 10.1200/JCO.2010.27.9752

103. Cheng KKF, Lim YTE, Koh ZM, Tam WWS. Home-based multidimensional survivorship programmes for breast cancer survivors. Cochrane Database Syst Rev. (2017) 8:CD011152. doi: 10.1002/14651858.CD011152. pub2

104. Spector D, Deal AM, Amos KD, Yang H, Battaglini CL. A pilot study of a home-based motivational exercise program for african american breast cancer survivors: clinical and quality-of-life outcomes. Integr Cancer Ther. (2014) 13:121-32. doi: 10.1177/1534735413503546

105. Nock NL, Owusu C, Kullman EL, Austin K, Roth B, Cerne S, et al. A community-based exercise and support group program in African-American breast cancer survivors (ABCs). J Phys Ther Health Promot. (2013) 1:15-24. doi: 10.18005/PTHP0101003

106. Wilson DB, Porter JS, Parker G, Kilpatrick J. Anthropometric changes using a walking intervention in African American breast cancer survivors: a pilot study. Prev Chronic Dis. (2005) 2:A16.

107. Piacentine LB, Robinson KM, Waltke LJ, Tjoe JA, Ng AV. Promoting team-based exercise among African American breast cancer survivors. West J Nurs Res. (2018) 40:1885-902. doi: 10.1177/01939459187 95313

108. Moadel AB, Shah C, Wylie-Rosett J, Harris MS, Patel SR, Hall CB, et al. Randomized controlled trial of yoga among a multiethnic sample of breast cancer patients: effects on quality of life. J Clin Oncol. (2007) 25:4387-95. doi: 10.1200/JCO.2006.06.6027

109. Lynch BM, Nguyen NH, Reeves MM, Moore MM, Rosenberg DE, Wheeler MJ, et al. Study design and methods for the ACTIVity And TEchnology (ACTIVATE) trial. Contemp Clin Trials (2018) 64 112-7. doi: 10.1016/j.cct.2017.10.015

110. Spector D, Battaglini C, Groff D. Perceived exercise barriers and facilitators among ethnically diverse breast cancer survivors. Oncol Nurs Forum (2013) 40:472-80. doi: 10.1188/13.ONF.472-480

111. Oyekanmi G, Paxton RJ, Barriers to physical activity among African American breast cancer survivors. Psychooncology (2014) 23:1314-7. doi: $10.1002 /$ pon. 3527 
112. Jones A, Paxton RJ. Neighborhood disadvantage, physical activity barriers, and physical activity among African American breast cancer survivors. Prev Med Rep. (2015) 2 622-7. doi: 10.1016/j.pmedr.2015.07.010

113. Palmer NR, Kent EE, Forsythe LP, Arora NK, Rowland JH, Aziz NM, et al. Racial and ethnic disparities in patient-provider communication, quality-ofcare ratings, and patient activation among long-term cancer survivors. J Clin Oncol. (2014) 32:4087-94. doi: 10.1200/JCO.2014.55.5060

114. Christian AH, O'Malley D, Barac A, Miller SM, Hudson SV. Cardiovascular risk and communication among early stage breast cancer survivors. Patient Educ Couns (2017) 100:1360-6. doi: 10.1016/j.pec.2017.02.010

115. Allicock M, Campbell MK, Valle CG, Carr C, Resnicow K, Gizlice Z. Evaluating the dissemination of Body \& Soul, an evidence-based fruit and vegetable intake intervention: challenges for dissemination and implementation research. J Nutr Educ Behav. (2012) 44:530-8. doi: 10.1016/j.jneb.2011.09.002

116. Resnicow K, Campbell M, Carr C, McCarty F, Wang T, Periasamy $\mathrm{S}$, et al. Body and soul. A dietary intervention conducted through African-American churches. Am J Prev Med. (2004) 27:97-105. doi: 10.1016/j.amepre.2004.04.009

117. Cassel KD, Braun K, Ka'opua L, Soa F, Nigg C. Samoan body and soul: adapting an evidence-based obesity and cancer prevention program. Qual Health Res. (2014) 24:1658-72. doi: 10.1177/1049732314549021

118. Phillips SM, Dodd KW, Steeves J, McClain J, Alfano CM, McAuley E. Physical activity and sedentary behavior in breast cancer survivors: new insight into activity patterns and potential intervention targets. Gynecol Oncol. (2015) 138:398-404. doi: 10.1016/j.ygyno.2015.05.026

119. Boyle T, Vallance JK, Buman MP, Lynch BM. Reallocating time to sleep, sedentary time, or physical activity: associations with waist circumference and body mass index in breast cancer survivors. Cancer Epidemiol Biomarkers Prev. (2017) 26:254-60. doi: 10.1158/1055-9965.EPI-16-0545

120. Fogg BJ. A behavior model for persuasive design. In: Persuasive '09 Proceedings of the 4th International Conference on Persuasive Technology, Claremont, CA (2009).

121. Cases MG, Fruge AD, De Los Santos JF, Locher JL, Cantor AB, Smith KP, et al. Detailed methods of two home-based vegetable gardening intervention trials to improve diet, physical activity, and quality of life in two different populations of cancer survivors. Contemp Clin Trials (2016) 50 201-12. doi: 10.1016/j.cct.2016.08.014

122. Pisu M, Demark-Wahnefried W, Kenzik KM, Oster RA, Lin CP, Manne S, et al. A dance intervention for cancer survivors and their partners (RHYTHM). J Cancer Surviv. (2017) 11:350-9. doi: 10.1007/s11764-016-0593-9

123. Patterson RE, Haines PS, Popkin BM. Diet quality index: capturing a multidimensional behavior. J Am Diet Assoc. (1994) 94:57-64. doi: 10.1016/0002-8223(94)92042-7

124. Hu FB. Dietary pattern analysis: a new direction in nutritional epidemiology. Curr Opin Lipidol. (2002) 13:3-9.

125. Willett WC, McCullough ML. Dietary pattern analysis for the evaluation of dietary guidelines. Asia Pac J Clin Nutr. (2008) 17(Suppl. 1):75-8.

126. Buford TW, Roberts MD, Church TS. Toward exercise as personalized medicine. Sports Med. (2013) 43:157-65. doi: 10.1007/s40279-013-0018-0
127. Jones LW, Eves ND, Scott JM. Bench-to-bedside approaches for personalized exercise therapy in cancer. Am Soc Clin Oncol Educ Book (2017) 37 684-94. doi: 10.14694/EDBK_173836

128. Goode AD, Lawler SP, Brakenridge CL, Reeves MM, Eakin EG. Telephone, print, and Web-based interventions for physical activity, diet, and weight control among cancer survivors: a systematic review. J Cancer Surviv. (2015) 9:660-82. doi: 10.1007/s11764-015-0442-2

129. Powe BD. Health information seeking among rural african americans, caucasians, and hispanics: it is built, did they come? Nurs Clin North Am. (2015) 50:531-43. doi: 10.1016/j.cnur.2015.05.007

130. Hamel LM, Penner LA, Eggly S, Chapman R, Klamerus JF, Simon MS, et al. Do patients and oncologists discuss the cost of cancer treatment? an observational study of clinical interactions between African American patients and their oncologists. J Oncol Pract. (2017) 13:e249-58. doi: 10.1200/JOP.2016.015859

131. Swanberg JE, Nichols HM, Ko J, Tracy JK, Vanderpool RC. Managing cancer and employment: Decisions and strategies used by breast cancer survivors employed in low-wage jobs. J Psychosoc Oncol. (2017) 35:180-201. doi: 10.1080/07347332.2016.1276503

132. Courneya KS, Rogers LQ, Campbell KL, Vallance JK, Friedenreich CM. Top 10 research questions related to physical activity and cancer survivorship. Res Q Exerc Sport (2015) 86:107-16. doi: 10.1080/02701367.2015. 991265

133. Breiman L. Random forests. Mach Learn. (2001) 45:5-32. doi: 10.1023/A:1010933404324

134. Kerr J, Patterson RE, Ellis K, Godbole S, Johnson E, Lanckriet G, et al. Objective Assessment of physical activity: classifiers for public health. Med Sci Sports Exerc. (2016) 48:951-7. doi: 10.1249/MSS.00000000000 00841

135. Kang JH, Park CH, Kim SB. Recursive partitioning clustering tree algorithm. Pattern Anal Appl. (2016) 19:355-67. doi: 10.1007/s10044-0140399-1

136. Asparouhov T, Muthen B. Structural equation models and mixture models with continuous nonnormal skewed distributions. Struct Equ Model. (2016) 23:1-19. doi: 10.1080/10705511.2014.947375

137. Paxton RJ, Zhang L, Wei C, Price D, Zhang F, Courneya KS, et al. An exploratory decision tree analysis to predict physical activity compliance rates in breast cancer survivors. Ethn Health (2017) 1-13. doi: 10.1080/13557858.2017.1378805

Conflict of Interest Statement: The authors declare that the research was conducted in the absence of any commercial or financial relationships that could be construed as a potential conflict of interest.

Copyright (c) 2019 Paxton, Garner, Dean, Logan and Allen-Watts. This is an openaccess article distributed under the terms of the Creative Commons Attribution License (CC BY). The use, distribution or reproduction in other forums is permitted, provided the original author(s) and the copyright owner(s) are credited and that the original publication in this journal is cited, in accordance with accepted academic practice. No use, distribution or reproduction is permitted which does not comply with these terms. 